\title{
DUTIES OF REASONABLE ACCOMMODATION IN RELATION TO RELIGION AND THE EUROPEAN COURT OF HUMAN RIGHTS: A CLOSER LOOK AT THE PROHIBITION OF DISCRIMINATION, THE FREEDOM OF RELIGION AND RELATED DUTIES OF STATE NEUTRALITY
}

\author{
Kristin Henrard ${ }^{*}$
}

\begin{abstract}
This article aims to answer the question of whether duties of reasonable accommodation on the basis of religion can and should be identified by the European Court of Human Rights. Throughout the article, it is emphasised that duties of reasonable accommodation are ultimately about realising equal opportunities and thus substantive equality by levelling out the playing field and evening out barriers to full participation. Duties of differential treatment under the prohibition of discrimination and the prohibition of indirect discrimination are both general in application and, arguably, provide a solid basis for duties of reasonable accommodation, including those relating to religion. Consequently, it is argued that identifying these duties of reasonable accommodation would seem to be a logical development of the Court's jurisprudence. It will be argued that the potential tension with the prohibition of discrimination (regarding those that cannot benefit from the accommodation measures) can be solved when an asymmetrical approach to the scrutiny of suspect grounds is adopted. Similarly, the apparent conflict with duties of state neutrality under the freedom of religion disappears when an inclusive vision of state neutrality is followed. When reasonable accommodation measures trigger controversies, this should be countered by awareness raising about the intrinsic connection of reasonable accommodation measures with substantive equality.
\end{abstract}

Keywords: Duties of reasonable accommodation; the prohibition of discrimination; asymmetrical approach to levels of scrutiny; freedom of religion; inclusive state neutrality; substantive equality; effective participation

Several recurring controversies pertaining to religious minorities, and especially new religious minorities, demonstrate that the existing societal structures are not adapted to their religiously inspired needs. Persons belonging to these minorities encounter difficulties, inter alia, in relation to their dress code, their wish to respect their religious holy days and weekly day of rest (which are different from the official days of rest), their wish to respect religiously inspired dietary requirements and the like. In several respects, these difficulties can be translated in terms of a lack of accommodation of their special needs. This raises the following interesting question about the relationship between law and religion, and between law and religious diversity: can and should duties of reasonable accommodation on the basis of religion be identified? The focus of this contribution will be on Europe, and more particularly, the supervisory bodies of the European Convention on Human Rights. The European Court of Human Rights (ECtHR) is undoubtedly the European court with the most extensive and wellknown jurisprudence on human rights, ${ }^{1}$ which, in several respects, still builds on the

Professor of Minority Protection at the Erasmus University Rotterdam.

See also R.K.M. Smith, Textbook on International Human Rights (2007), at 89. The European Court of Justice of the EU has undoubtedly developed a sizeable human rights jurisprudence as well (see inter alia R.A. Lawson, 'Stuifzand of kruisbestuiving? Over de invloed van het Unierecht op de rechtspraak van het EHRM', 35 NJCM Bulletin Special Edition: 60 jaar EVRM 7, at 783-796 (2010); R.A. Lawson, 'Over laserguns, rode sterren en een voorzichtig ontluikende liefde tussen twee dames op leeftijd', 31 NJCM Bulleting Special edition: 55 jaar EVRM 1, at 146-162 (2006)), but this is not the case for religious matters. Besides, the upcoming ratification of the ECHR by the EU confirms that the ECtHR has the final word on the interpretation of human rights in Europe. 
jurisprudence of the former European Commission on Human Rights. So far, explicit duties of reasonable accommodation are absent from the jurisprudence of the Court. The Court actually confirmed in Kosteski $v$ the Former Yugoslav Republic of Macedonia, ${ }^{2}$ that it, like the former Commission, ${ }^{3}$ is not willing to establish an explicit duty of reasonable accommodation of religious differences which would require a state to take reasonable measures to ensure the effective enjoyment of the freedom to manifest one's religion, also for members of religious minorities. ${ }^{4}$

Other articles have analysed the jurisprudence of the Court and the Commission in depth, and have identified the extent to which these supervisory bodies de facto require states to accommodate religious diversity, in addition to criticising the multiple ways in which they do not (adequately) do so. ${ }^{5}$ This article is more normative in nature, and seeks to make the argument that the Court should establish duties of reasonable accommodation on the ground of religion, particularly given its steady lines of jurisprudence. In this respect, possible obstacles to the identification of such duties need to be, and are, addressed.

In order to answer these questions, it appears, first of all, essential to clarify the meaning, ratio and scope of duties of reasonable accommodation. These duties are indeed, a rather recent phenomenon, especially in Europe. ${ }^{6}$ It will be emphasised throughout this article that duties of reasonable accommodation are ultimately about realising equal opportunities, and thus about substantive equality, particularly by levelling out the playing field and evening out barriers to full participation. ${ }^{7}$ It will, furthermore, be noted that, while currently duties of reasonable accommodation in Europe tend to be confined

Kosteski v the Former Yugoslav Republic of Macedonia, ECHR (2006), Application 55170/00.

Konttinnen v Finland, ECommHR (1996), Application 24949/94: concerned a man working at the state railways who joined the Seventh Day Adventist Church. That religion has sabbath duty from sunset on Friday to Saturday. Only a few Fridays in winter this meant that he had to leave early from work. His dismissal for these unauthorized absences did not even raise issues under Article 9(1) as these absences were not accepted as manifestations of his religion.

In Stedman v UK, ECommHR (1997), Application 29107/95, a private sector employer dismissed an employee who did not want to work on Sunday. The Commission relied on its Konttinnen reasoning and concluded that a fortiori unauthorized absences from work for religions reasons are not protected in relations between private persons (there would not be a positive obligation for the state to ensure that private employers would accept this behaviour from their employees).

A similar refusal to identify duties of reasonable accommodation was visible in Ahmed $v U K$, ECommHR (1981), Application 22954/93, where the Commission held that a dismissal related to absences from work to fulfill religious observances does not amount to an interference: the person concerned had accepted the position knowing that the work schedule would prove incompatible with the fulfillment of particular religious observances.

See also the inadmissibility decision in Dahlab v Switzerland, ECHR (2001), Application 42393/98, in which the Court was not ready to identify duties of reasonable accommodation concerning religious dress and dress code in a particular employment setting (a public school teacher).

J. Ringelheim, Diversité Culturelle et droits de l'homme, L' emergence de la problematique des minorities dans le droit de la Convention Europeenne des Droits de l'Homme (2006), at 169.

Inter alia K. Henrard, 'Freedom of Religion and Religious Minorities: An Adequate Accommodation of Religious Diversity?', published in Spanish ('Libertad de religion y minorias religiosas: una adaptacion adecuada de la diversidad religiosa?'), in E.J. Ruiz Vieytez \& G. Urrutia Asua (eds.), Derechos humanos $y$ diversidad religiosa (2010), at 247-276; K. Henrard, 'A Critical Appraisal of the Margin of Appreciation Left to States Pertaining to 'Church-state Relations' Under the Jurisprudence of the ECtHR', to be published in M.C. Foblets et al (eds.), A Test of Faith? Religious Diversity and Accommodation in the European Workplace (2012), at 24 (chapter 3).

Inter alia L. Waddington, 'Reasonable Accommodation', in D. Schiek, L. Waddington and M. Bell (eds.), Cases, Materials and Text on National, Supranational and International Non-discrimination Law (2007), at 630 .

See inter alia P. Bosset, Reflections on the Scope and Limits of the Duty of Reasonable Accommodation in the Field of Religion (2005), at 1; M. Jézéquel, 'The Reasonable Accommodation Requirement: Potential and Limits', in Council of Europe (ed.), Institutional Accommodation and the Citizen: Legal and Political Interaction in a Pluralist Society (2010), at 4-27. Bosset and Foblets add to this line of reasoning that, as far as possible, democratic states must allow everyone to participate fully in society on an equal footing. This would be the main underlying idea of reasonable accommodation: see P. Bosset and M.C. Foblets, 'Accommodating Diversity in Québec and Europe: Different Legal Concepts, Similar Results?', in Council of Europe (ed.), Institutional Accommodation and the Citizen: Legal and Political Interaction in a Pluralist Society (2010), at 37. 
to persons with a disability, the origins of thinking in terms of duties of accommodation lie in experiments in the US ${ }^{8}$ and Canada concerning religious diversity (resulting from immigration).

Thus, it is not strange to investigate whether, on the basis of the existing equality doctrine, a case can indeed be made for duties of reasonable accommodation in relation to religion. It will be argued that one can indeed identify at least two dimensions of the prohibition of discrimination that are closely related to, and interrelated with, duties of reasonable accommodation, namely duties of differential treatment and the prohibition of indirect discrimination. As these dimensions of the prohibition of discrimination are not confined to particular grounds, ${ }^{9}$ they are also valid for the ground of religion. In this regard, it seems indeed possible to argue that the identification of duties of reasonable accommodation in relation to religion would be a logical development of the ECtHR's jurisprudence.

Subsequently, it is important to check whether these duties can also be reconciled with the general human rights framework, including the equality doctrine in general, and the freedom of religion. In the latter evaluation, theoretical considerations are combined with an analysis of the relevant jurisprudence of the European Court of Human Rights, whilst regard is given to the standards, jurisprudence and developments in the US and Canada pertaining to duties of reasonable accommodation.

Potential conflicts between religious accommodation measures and the prohibition of discrimination on the basis of religion (towards persons that are not subject to the accommodation) will also be addressed, as will tensions between these measures and duties of state neutrality. It will be argued that these potential conflicts can be reconciled in a way which promotes the overall coherence of the human rights framework, confirming its holistic nature. In the process, a case is made for an asymmetrical approach towards the scrutiny of suspect grounds of differentiation (under the prohibition of discrimination), and for an inclusive vision of neutrality (towards the duties of state neutrality under the freedom of religion). In particular, the reasoning related to the asymmetrical approach towards non-discrimination relies on the underlying goals of reasonable accommodation, namely substantive equality and equal opportunities, levelling out the playing field by evening out barriers to full participation.

Underscoring and raising awareness about these legitimate goals of duties of reasonable accommodation is, arguably, important in reducing the controversies they often trigger. Furthermore, and also important in reducing misunderstandings and related controversies, these duties are not duties of absolute accommodation but of reasonable accommodation, as the concept itself already clarifies. Hence, the inherent limits of duties of reasonable accommodation merit discussion.

Finally, the conclusion draws the different threads together, supporting the identification of duties of reasonable accommodation on the basis of religion by the ECtHR, while considering the coherence and holistic nature of the human rights paradigm, the importance of awareness raising, as well as possible developments from reactive to more pro-active forms of accommodation..$^{10}$

\section{Duties of Reasonable Accommodation: Ratio and Scope in a Historical Perspective}

While duties of reasonable accommodation are a fairly new concept in European equality law, they are used explicitly in the legislation and jurisprudence of an increasing

\footnotetext{
The Civil Rights Act of 1964 was amended in 1972 to include a duty on the employer to accommodate the religious practices of employees, unless this would cause undue hardship to the employer.

9 See also Jézéquel, above n. 7, at 26-27, who highlights the general applicability of duties of reasonable accommodation in Canada. She identifies the general group of beneficiaries of reasonable accommodation as those that are vulnerable, either because they belong to a historically disadvantaged group or because they are individuals with personal characteristics and a degree of social fragility that expose them to the risk that their interests will be neglected. She refers, in this respect, to existing social reality.

${ }_{10}$ It will be argued below that the ECtHR already recognises de facto duties of reasonable accommodation on the basis of religion in particular cases.
} 
number of a variety of states, such as the US, Canada, South Africa, New-Zealand and Israel. Hence, it is not surprising that they also feature in treaties and legislative texts of international organisations, such as the UN and the EU. It cannot be denied that there are differences in formulation, as well as in scope, of the duties of reasonable accommodation, both concerning the grounds of differentiation and the societal fields to which they apply. Strikingly, and as will be further elaborated upon below, the international standards (of the UN and the EU) are confined to the ground of disability. Nevertheless, it is possible to identify the core meaning and the underlying ratio of duties of reasonable accommodation.

The underlying ratio for the duty of reasonable accommodation is related to the quest for equality, in particular substantive equality. In the end, duties of reasonable accommodation are about realising equal opportunities, levelling out the playing field by evening out barriers to full participation, ${ }^{11}$ such as (de facto) unequal access to employment, to public services, to education ${ }^{12}$ and, more broadly, to social services. In other words, accommodation measures are meant to address barriers to participation that particular (groups of) persons ${ }^{13}$ are confronted with due to an interaction between an individual's inherent characteristics, and the physical or social environment. Bosset and Foblets argue in this respect that 'the main idea underlying reasonable accommodation is that democratic states must allow everyone to participate fully in society on an equal footing, as far as possible.... ${ }^{14}$

A characteristic which comes to mind almost naturally in this respect is impairment or disability. Using the example of disability as a ground of differentiation, ${ }^{15}$ one can think of the de facto inability to perform a particular function or job in the conventional manner, or to have actual access to services, due to a disability. ${ }^{16}$ Duties of reasonable accommodation in the employment sphere in relation to disability could, for example, consist of - depending on the circumstances and the disability - physical adaptations to the working place, adapted working hours or other instances of job restructuring.

When talking about barriers to participation, it is obvious that other personal characteristics can also be relevant in this respect, in particular, religion, language, culture, race and sex. ${ }^{17}$ The examples in the introduction already referred to barriers to full and equal participation relating to particular religions and religious prescripts. When persons with a particular type of religious dress are not allowed to do a particular job or get access to a particular location, or to receive a particular service, this arguably amounts to numerous barriers to participation. Similarly, when the rigid use of working schedules or periods in which one can take a day off inhibits persons to comply with their religious prescripts pertaining to prayer, visits to places of worship and the like, this similarly complicates their effective participation in the societal fields concerned. The reasonable accommodation in this respect would consist of, for example, allowing religiously inspired dress and introducing flexible working hours. ${ }^{18}$

\footnotetext{
11 See also G. Bouchard and C. Taylor, Building the Future. A Time for Reconciliation (abridged report) (2008), at 68, where it is emphasised that accommodations are, above all, intended to protect minorities against shortcomings in the laws of the majority, not the opposite. The related forms of different treatment do not amount to granting a privilege, but are meant to engage in a reasonable adaptation to counteract the rigidity of certain rules or their uniform application, regardless of the specific traits of individuals.

12 For an interesting discussion of the reasonable accommodation debates pertaining to education in Québec, see M. Mc Andrew, 'The Muslim Community and Education in Québec: Controversies and Mutual Adaptation', 11 Migration and Integration 1 (2010).

13 See below for the discussion of the individual versus group dimension of duties of reasonable accommodation.

14 Bosset and Foblets, above n. 7, at 37.

15 It will be noted below that duties of reasonable accommodation are most widely identified in relation to the ground of disability.

16 See also Waddington (2007), above n. 6, at 631.

17 See below for the argument that religion should also be considered as a relevant inherent characteristic that can lead to barriers.

${ }_{18}$ As confirmed by E. Bribiosa, J. Ringelheim and I. Rorive, an accommodation can take various shapes: a mere exemption from a particular general rule, the creation of a special regime, the provision of infrastructures or particular services etc.: 'Reasonable Accommodation for Religious Minorities: A Promising Concept for European Anti-discrimination Law?', 17 Maastricht Journal 2, at 147-148 (2010). See also Jézéquel, above n. 7, at 28.
} 
An additional aspect of the scope of reasonable accommodation duties is, arguably, helpful in defusing potential controversies, and concerns the non-absolute nature of these duties, as is already captured to some extent in the concept itself: the adjective 'reasonable' is added to 'accommodation'. The limits of duties of accommodation tend to be captured under the heading of 'undue hardship' and/or 'disproportionate burden' in the relevant regulation and/or jurisprudence. ${ }^{19}$ Initially, in Canada undue hardship was only defined in reference to the interests of the one who needed to make the accommodation, including undue expense and undue interference in the operation of an employer's business. ${ }^{20}$ Later on, 'rights of others' were also included, and then one thinks primarily of those persons who cannot benefit from the accommodations concerned. ${ }^{21}$ In this respect, it is important to highlight that substantive equality is not only the goal, but also a limit, of duties of reasonable accommodation. ${ }^{22}$

In addition to the overarching justification of contributing to substantive equality, duties of reasonable accommodation can furthermore be argued as contributing to a better integration of the persons (groups) concerned. ${ }^{23}$ In order to reduce tensions and counter controversies elicited by (particular) accommodation measures ${ }^{24}$ it would be advisable to use awareness raising campaigns to underscore not only the goal of substantive equality, ${ }^{25}$ but also the positive relation with public concerns of integration, social cohesion and social harmony. ${ }^{26}$

\section{Individual versus Group Dimension}

The focus of duties of reasonable accommodation is the individual person belonging to a particular group. Indeed, reasonable accommodation measures tend to imply differential treatment that takes into account the specific features of individuals in order to tackle barriers to participation. In addition, in order to fulfill the goal of substantive equality, it is important that the accommodation measures are tailored to the specific characteristics of each and every (individual) case. At the same time, one refers to special needs of vulnerable, disadvantaged groups, implying that reasonable accommodation is meant to address the special needs and disadvantages of persons belonging to particular groups in terms of effective participation. ${ }^{27}$ In other words, duties of reasonable accommodation

\footnotetext{
19 A well-known example of the use of 'disproportionate burden' to denote the limits of duties of reasonable accommodation can be found in Article 5 of Directive 2000/78/EC establishing a general framework for equal treatment in employment and occupation.

${ }_{20}$ Bosset (2005), above n. 7, at 9. Relevant factors in this respect include the actual cost of the accommodation requested, sources of outside funding, the size of the business or institution, and the economic context, relative interchangeability of employees, impact on business productivity, duration and scope of the accommodation: see also Bossset and Foblets, above n. 7, at 49-53; C. Brunelle, Discrimination et obligation d'accommodement en milieu de travail syndiqué (2001), at 248-251.

21 See also Bosset (2005), above n. 7, at 10.

This will be further elaborated upon below, where the possible tension between duties of reasonable accommodation and the prohibition of discrimination is discussed.

22 See below for the analysis of the tension between duties of reasonable accommodation and the prohibition of discrimination.

23 Inter alia Bosset (2005), above n. 7, at 4. Cf. 'Advisory Committee on Integration and Reasonable Accommodation in Schools', Inclusive Quebec Schools: dialogue, values and common reference points, at 35-36 (2007). See also Bouchard and Taylor, above n. 11, at 55, where the authors point out that a request for accommodation which would favour ghettoisation would be likely to be rejected, whereas requests directed at integration would have a greater chance of being accepted. An example they provide concerns a request pertaining to the wearing of religious signs in school: allowing this would enable Sikh, Muslim or Jewish students to attend public schools instead of private religious schools.

24 The appointment and work of the Bouchard Taylor Commission (an advisory commission on the practices of accommodation) in reaction to the accommodation crisis in Quebec arguably follows the same logic of reducing controversies by making explicit the underlying considerations and goals of duties of reasonable accommodation: see also Bossset and. Foblets, above n. 6, at 54-55.

${ }_{25}$ See also R. Süssmuth, 'Reasonable or Mutual Accommodation? The integration debate in Germany', 28 Options Politiques 8, at 53 (2007), who opposes the German debate on integration from the Leitkultur perspective with the Common Basic Principles for Immigrant Integration Policy developed within the EU, as the first principle frames integration as a dynamic, two way process of mutual accommodation.

26 See also Jézéquel, above n. 7 , at 21.

27 Jackson Preece makes an explicit link between, on the one hand, structurally disadvantaged groups (the
} 
do have a certain group dimension in the sense that these duties are identified in relation to persons that possess a characteristic, which is used to denote or delineate particular groups. ${ }^{28}$

Admittedly, the extent of the group dimension inherent in thinking in terms of reasonable accommodation depends on the ground of differentiation concerned, as well as the kind of accommodation concerned. A disability is very individual-specific, as there are very many types of disability and degrees of disability. At the same time, it is obvious that when a ramp or an elevator is put in place in order to accommodate the working environment, this will benefit many persons in similar situations. Adaptations to the individual desk of a disabled employee on the other hand are clearly individualised. Allowing religiously inspired dress or flexible working schedules may be in response to an individual request, but this can/will be relevant for persons that belong to the religious group concerned.

The recognition of the group dimension implicated in reasonable accommodation measures can also develop over time. This was clearly the case in Canada where reasonable accommodations were initially clearly considered to be an individually tailored measure of a re-active kind. However, increasingly, pro-active group solutions have also been envisaged, through the adaptation of general standards. ${ }^{29}$

\section{A Historical Perspective}

In view of the focus of this special issue on the relationship between law and religion, and the central research question of this contribution concerning the legitimacy (in terms of the human rights framework) of duties of reasonable accommodation on the basis of religion, it appears particularly appropriate to emphasise that duties of reasonable accommodation were originally conceptualised in order to deal with religious diversity ${ }^{30}$ resulting from immigration waves in the US and Canada. ${ }^{31}$ It is furthermore striking how the concept has experienced a different evolution in the two countries: in several respects it has obtained a broader ambit under Canadian Law than under American law. ${ }^{32}$

The US was the first country to officially recognise duties of reasonable accommodation. These were first acknowledged in the framework of the 1964 Civil Rights Act where, following an amendment in 1972, a duty was added under Title VII for private or public employers to 'reasonably accommodate to an employee's or prospective employee's religious observance or practice without undue hardship on the conduct of the employer's business ${ }^{33}$ However, there was no development in the

members of which would qualify for duties of reasonable accommodation) and, on the other, minorities (J. Jackson Preece, 'Emerging Standards of Reasonable Accommodation Towards Minorities in Europe?', in Council of Europe (ed.), Institutional Accommodation and the Citizen: Legal and Political Interaction in a Pluralist Society (2010), at 120). She emphasises, in this respect, that 'history demonstrates that in a pluralist society comprised of a variety of ethnic, cultural, racial and other identities, majority public opinion tends to disadvantage minority groups in the market place for social goods' (id., at 119).

28 See also Jackson Preece, above n. 27, at 119.

29 See below on the developments in Canada, where increasingly, pro-active accommodation is also envisaged through the adaptation of general standards.

30 It should be emphasised that duties of reasonable accommodation on the of basis religion are also related to the (effective enjoyment of the) freedom to manifest one's religion in Canada (inter alia J. Woehrling, 'La Liberté de religion, l'obligation de neutralité religiouse de l'état et le droit à l'accommodement raisonable': quelle place pour la religion dans les institutions publiques?', 33 Revista catalana de dret public, at 369-403 (2006)), in the US the free exercise clause: see inter alia S.A. Rosenzweig, 'Restoring Religious Freedom to the Workplace: Title VII, RFRA and Religious Accomodation', 144 University of Pennsylvania Law Review 6, at 2517-2530 (1996). See also below.

31 The 1972 amendments to the 1968 Civil Rights Act introduced the concept 'reasonable accommodation' but the actual practice already existed earlier on in the practice of the Equal Employment Commission (Regulations 20 CFR 1605.2(c)). This Committee argued that the obligation not to discriminate on the basis of belief also implied a duty to adopt reasonable accommodation measures in relation to religious practices of employees, unless this would entail 'undue hardship'. See also Bribiosa, Ringelheim and Rorive, above n. 18 , at 143 .

32 Inter alia Bosset and Foblets, above n. 7, at 43-50; Bribiosa, Ringelheim and Rorive, above n. 18, at 139 .

33 Civil Rights Act 1964, Title VII, Chapter 21, par 701(j). See also J.M. Oleske Jr., 'Federalism, Free 
US towards an encompassing notion of duties of reasonable accommodation. In the end, duties of reasonable accommodation are only acknowledged in relation to two grounds, with the most meaningful development of reasonable accommodation duties clearly developed in relation to the ground of handicap. ${ }^{34}$ Indeed, the scope of duties of reasonable accommodation is markedly different for the two grounds. The undue hardship clause concerning reasonable accommodation duties on the ground of religion was interpreted in a very lenient way in relation to religious diversity, in the sense that when an accommodation would require the bearing of anything more than a de minimis cost, it would entail undue hardship..$^{35}$ Consequently, the exact scope of reasonable accommodation duties on this ground was minimal. ${ }^{36}$ This is markedly different from the ground handicap, where the American with Disabilities Act defines undue hardship as an 'action requiring significant difficulty or expense' ${ }^{37}$

In Canada, duties of reasonable accommodation were introduced by the Courts through an interpretation of equality and non-discrimination principles. ${ }^{38}$ The leading case of O'Malley v Simpsons Sears (1985) concerns a salesperson who was denied accommodation of the working hours she required in order to strictly observe shabbath. This denial was held to contravene the equality principle, as the Supreme Court specified that duties of reasonable accommodation are a natural component of the right to equal treatment. ${ }^{39}$ This generous interpretation was subsequently extended to the interpretation of the equality clause in the Canadian Charter of Rights and Freedoms, and is indeed accepted (by the courts) in relation to all 14 enumerated grounds of prohibited discrimination in section 15 , as well as analogous grounds. ${ }^{40}$ In view of this quality of inherent dimension of the right to equal treatment, its field of application is broad, also concerning the subject matter areas (the fields of societal life). ${ }^{41}$

The Supreme Court's interpretation of undue hardship is also more robust in the sense that 'more than a mere negligible effort is required to satisfy the duty to accommodate in relation to all grounds, thus also religion. The use of the term 'undue' infers that some hardship is acceptable; it is only undue hardship that satisfies this test' ${ }^{42}$

Nevertheless, and notwithstanding the surge of public attention for accommodation on the ground of religion, especially in 2006-2007 in the province Québec, ${ }^{43}$ it should be acknowledged that religion is not the ground which is most prevalent for duties of

Exercise and Title VII: Reconsidering Reasonable Accommodation', 6 University of Pennsylvania Journal of Constitutional Law, at 532 (2004).

34 The developments of duties of reasonable accommodation on the basis of handicap took place in relation to the American with Disabilities Act (1990), 42 U.S.C. par 12111(10).

35 The leading case of the US Supreme Court is Trans World Airlines v Hardison, 432 U.S. 63 (1977).

36 The undue hardship clause was actually interpreted in such a way that the duty to make reasonable accommodation would not go beyond 'de minimis costs' (inter alia Trans World Airlines Inc v Hardison, 432 US 63 (1977)). Consequently, the impact of the duty was very limited (inter alia J.B. Cromwell, 'Cultural Discrimination: The Reasonable Accommodation of Religion in the Workplace', 10 Employee Responsibilities and Rights Journal 2, at 156-159 (1997)). See also Rosenzweig, above n. 30, at 2517-2522.

37 For a critical perspective to this jurisprudence see inter alia K. Engle, 'The Persistence of Neutrality: The Failure of the Religious Accommodation Provision to Redeem Title VII', 76 Texas Law Review 2, at 387-406 (1997).

38 It should be noted though that Canadian judges have also inferred the duty of reasonable accommodation from the right to religious freedom: see inter alia Bribiosa, Ringelheim and Rorive, above n. 18 at 146-147.

39 Note that the Ontario Human Rights code was amended in 1986 to explicitly introduce the duty of reasonable accommodation (R.S.O. 1990 (Ontario) c H19, Article 11, 24).

${ }_{40}$ Bosset (2005), above n. 7, at 2. See also Employment Equity Act para. 5(b).

41 It should be noted that the Supreme Court limited the reach of duties of reasonable accommodation in relation to the legislator in Alberta v Hutterian Brethren of Wilson Colony, 2009 SCC37, [2009] 2 S.C.R. 567, especially at paragraph 69 , where it emphasised that 'by their very nature, laws of general application are not tailored to the unique needs of individual claimants. The legislature has no capacity or legal obligation to engage in such an individualized determination...'.

${ }_{42}$ Central Okagan School District No 23 v Renaud, [1992] 2 S.C.R. 970, at 984. See also Jézéquel, above n. 7 , at 29-32.

43 The controversies concerning particular instances of reasonable accommodation on grounds of religion in Québec actually triggered the establishment of the Bouchard-Taylor commission, see above n. 11 . 
reasonable accommodation. The more frequent grounds of reasonable accommodation duties are (in order of frequency) disability, ${ }^{44}$ gender, ${ }^{45}$ age $^{46}$ and national origin. ${ }^{47}$

Finally, it should be highlighted that the jurisprudence of the Canadian courts has actually acknowledged that reasonable accommodation may take the form of individual and specific exemptions from rules or standards, and institutions are required to consider the situation of the affected groups when formulating the standards. ${ }^{48}$ In other words, the accommodation is required to be incorporated in the standard itself. In the words of Bosset and Foblets: 'to avoid discrimination proceedings, therefore ... institutions should in principle adapt their rules and standards, even before receiving any individual requests for adjustments or exemptions. Thus, by influencing the actual formulation of standards, accommodation becomes less reactive and more structural. It now plays a preventive, and even proactive, rather than a purely corrective role'. ${ }^{49}$

When considering the data available on national and international regulations pertaining to duties of reasonable accommodation, it becomes clear that in most national regulations, duties of reasonable accommodation are limited to particular grounds, generally including disability, and often also religion..$^{50}$ This is different from countries like Canada and South Africa, where accommodation duties are explicitly seen as an inherent dimension of the equality principle or the principle of non-discrimination: in these countries duties of reasonable accommodation can also be identified in relation to other grounds, such as age or gender. As it stands, duties of accommodation are only explicitly recognised in UN treaties and EU legislation for the ground of disability. ${ }^{51}$ Nevertheless, the European Court of Justice already recognised in 1976 de facto duties of reasonable accommodation on the ground of religion in its Vivien Prais judgment, concerning the setting of a date for an open competition (exam). The judgment clarifies that the general principle of equal treatment implies that European institutions must, as much as possible, accommodate the dates of the tests to religious observances. ${ }^{52}$

Arguably, the preceding paragraphs with an historical perspective to duties of reasonable accommodation demonstrate that legislative choices to focus on a particular ground of differentiation do not imply that duties of reasonable accommodation cannot be used more widely, also in relation to other grounds. ${ }^{53}$ Indeed, in several respects the exact scope of duties of reasonable accommodation depends on interpretative choices, ultimately by courts and other supervisory bodies, (inter alia) pertaining to the right to equal treatment and the prohibition of discrimination as embracing substantive equality and equal opportunities (concerning effective participation).

44 CEGEP John-Abbott c Blouin, CS Montréal, no. 500-17-018750-045, 10 June 2004.

45 Commission des droits de la personne c Lingerie Roxana [1995] RJQ 1289 (TDP).

46 Desroches c Commission des droits de la personne du Quebec [1997] RJQ 1540 (CA).

47 For an overview of case law on duties of reasonable accommodation on grounds other than religion, see P. Bosset, Les accommodements raisonnable: quoi, comment, jusqu'où? (2007), at 13-14.

48 British Columbia (Superintendent of Motor Vehicles) v British Columbia (Council of Human Rights), [1999] 3 SCR 868 (Grismer), at paragraph 19, where employers and others are invited 'in all cases to accommodate the characteristics of affected groups within their standards, rather than maintain discriminatory standards supplemented by accommodation for those who cannot meet them.' See also Britisch Columbia (Public Service Employee Relations Commission) v BCGSEU, [1999], 3 SCR 3 (Meiorin).

49 Bosset and Foblets, above n. 7, at 45.

50 See also the UN Enable document which shows that for example in New Zealand duties of reasonable accommodation exist in relation to the same two grounds as in the US.

51 Directive 2000/78/EC establishing a general framework for equal treatment in employment and occupation, Article 5; UN Convention on the Rights of Persons with Disabilities, Article 5, 3.

52 Case C-130/75 Vivien Prais v Council [1976] ECR 1589. In casu the complaint was rejected because the applicant had notified the institution too late (after the date that the other candidates had been invited). Nevertheless, the ECJ does point out that it is 'desirable that an appointing authority informs itself in a general way of dates which might be unsuitable for religious reasons, and seeks to avoid fixing such dates for tests' (para. 18).

53 Inter alia Waddington and Bell who argue that an analogous duty to make reasonable accommodation would be just as justified in relation to the grounds race and religions (referring to persons belonging to minorities) and even age: M. Bell and L. Waddington, 'Reflecting on Inequalities in European Equality Law', 28 European Law Review 3, at 362 (2003). 


\section{Duties of Reasonable Accommodation on the Basis of Religion as Mandated by Equality Doctrine?}

The previous paragraphs already underscored the relationship between, on the one hand, duties of reasonable accommodation and, on the other, the equality principle/the right to equal treatment. Duties of reasonable accommodation are clearly aimed at true, genuine or substantive equality. In several jurisdictions, it is also accepted that these duties of reasonable accommodation are an intrinsic component or dimension of the right to equal treatment. In the countries concerned, duties of reasonable accommodation apply to all grounds of differentiation.

In the following paragraphs, it will be investigated to what extent duties of reasonable accommodation can indeed be argued to be a generic component of the right to equal treatment, and thus also applicable to the ground of religion. While the focus is on the more generally valid lines of interpretation, the (potential) implications for religion and religious diversity are highlighted.

Initially, the interpretation of the prohibition of discrimination tended to be geared towards formal or mathematical equality, as opposed to genuine or substantive equality. ${ }^{54}$ However, the jurisprudence of supervisory bodies have constructed dimensions of the prohibition of discrimination which imply numerous openings towards genuine or substantive equality. ${ }^{55}$ Two of these are particularly relevant for the purposes of this article: duties of differential treatment under the prohibition of discrimination and the prohibition of indirect discrimination. In short, whereas duties of reasonable accommodation can be argued to be a particular kind of duties of differential treatment aimed at substantive equality; accommodation measures can be considered as important tools to prevent or remedy instances of indirect discrimination.

Already during the time of the philosopher Aristotle, the paradox of the equality principle was recognised. This paradox implies that it may be necessary to use formally differential treatment, which takes into account special circumstances, in order to realise substantive equal treatment. Indeed, according to this ancient philosopher, one needs to treat equally what is equal but unequally what is unequal to the extent of the inequality. ${ }^{56}$ This line of thinking is explicitly taken up by the European Court of Justice in relation to the general principle on equal treatment. It should, however, be acknowledged that this has so far only entailed one recognition of a de facto duty of reasonable accommodation, namely in the Vivien Prais judgement, referred to above.

The European Court of Human Rights only followed suit in 2000 with its seminal judgment of Thlimmenos $v$ Greece, in which it stated that 'the right not to be discriminated against in the enjoyment of the rights guaranteed under the Convention is also violated when States without objective and reasonable justification fail to treat differently persons whose situations are significantly different ${ }^{57}$ Interestingly, this case concerned a person belonging to a religious minority, namely a Jehovah witness, who was denied an appointment as a chartered accountant because he had been convicted of a serious crime for having refused to carry out military service due to religious reasons. The Court accepted that the relevant legislation pursued the legitimate aim of preventing dishonest or untrustworthy people from the profession of chartered accountant. However, it emphasised that a conviction for being a conscientious objector cannot be considered to denote his untrustworthiness or dishonesty. Thus, there was no reasonable and objective justification for nevertheless applying this rule to Thlimmenos. ${ }^{58}$

\footnotetext{
54 See inter alia K. Wentholt, 'Formal and Substantive Equal Treatment: the Limitations and Potential of the Legal Concept of Equality', in T. Loenen and P.R. Rodriguez (eds.), Non-Discrimination Law: Comparative Perspectives (1999), at 58.

55 See inter alia K. Henrard, 'Non-discrimination and the Equality Principle', in M. Weller (ed.), Jurisprudence Digest: Minority Protection (2006). See also Jackson Preece, above n. 27, at 112.

56 Aristotle, Politea, 1280a (trans. T. Saunders, 1995).

57 Thlimmenos v Greece, ECHR (2000) Application 34369/97, at paragraph 44. This judgment can be related to the reasoning of one of the Supreme Court of Canada's judges in the seminal case Andrews $v$ Law Society of British Columbia: 'difference in treatment between individuals under the law will not necessarily result in inequality and ... identical treatment may frequently produce serious inequality'.

58 Thlimmenos $v$ Greece, id., at paragraph 47.
} 
Duties of reasonable accommodation fit the scheme of duties of differential treatment perfectly, ${ }^{59}$ since they concern special measures for persons that are confronted with particular barriers to their effective participation, by which these special circumstances are taken into account. Some academics actually argue that Thlimmenos is a case where the Court de facto identifies duties of reasonable accommodation. ${ }^{60}$

However, so far, the ECHR has not developed the Thlimmenos rational in any significant manner, let alone by explicitly recognising duties of reasonable accommodation. ${ }^{61}$ The first proper reasonable accommodation application of Thlimmenos arguably only occurred in 2009, in Glor $v$ Switzerland, ${ }^{62}$ which concerned the duty of a disabled person to pay a military-service exemption tax. Glor actually wanted to perform his military service, but was declared unfit to do so. He nevertheless had to pay this tax, while persons with a major disability did not have to pay it. According to the Court, it would have been possible to provide for forms of military service compatible with the applicant's condition, or alternative forms of service. Since the Swiss authorities did not provide this opportunity (a de facto reasonable accommodation), they violated the prohibition of discrimination. ${ }^{63}$

It is furthermore striking that, in so far as the Court did identify a duty of differential treatment following Thlimmenos (not necessarily amounting to a form of reasonable accommodation), it seemed rather hesitant to do so in relation to the ground of religion. For example, in 2004, it already identified a special investigatory duty for suspicious deaths and use of violence when there were indications of racial animus. ${ }^{64}$ However, it only confirmed this line of reasoning for deaths with indications of religious discriminatory animus in 2010 in its Milanovic judgment ${ }^{65}$ (while it could have done so earlier). ${ }^{66}$

Nevertheless, a few days before Milanovic, the Court also identified a de facto duty to accommodate the dietary needs related to particular faiths in prisons. ${ }^{67}$ This could potentially point towards an enhanced willingness to identify de facto instances of duties of reasonable accommodation. We need to await future judgments to determine whether this is indeed the case.

Duties of reasonable accommodation, as more generally duties to adopt differential treatment, can also be related to the prohibition of indirect discrimination. ${ }^{68}$ Indirect discrimination concerns, at first sight, neutral measures which have nevertheless a disproportionate negative impact on persons belonging to particular groups, without this being reasonably and objectively justified. ${ }^{69}$ This disproportionate impact refers to ingrained habits and related systems in society, which proceed from the majority perspective, and thus do not take into account other perspectives, such as the perspective of the disabled, or the adherent of a minority religion. ${ }^{70}$ The prohibition of indirect

\footnotetext{
59 It definitely is relied upon heavily in the justification of duties of reasonable accommodation, for example, in Canada: see Bouchard and Taylor, above n. 11, at 23-24.

60 Ringelheim, Bribiosa and Rorive, above n. 18, at 154; L. Waddington, 'Reasonable Accommodation: Time to Extend the Duty to Accommodate Beyond Disability?', 36 NJCM Bulletin (2011), at 195.

${ }_{61}$ See also F. Ast, 'Indirect discrimination as a means of protecting pluralism: challenges and limits', in Council of Europe (ed.), Institutional Accommodation and the citizen: legal and political interaction in a pluralist society (2010), at 106-107.

${ }_{62}$ Glor v Switzerland, ECHR (2009) Application 13444/04. See also Jézéquel, above n. 7, at 313; Ringelheim, Bribiosa and Rorive, above n. 14, at 156; Waddington (2011), above n. 60, at 195.

63 Glor v Switzerland, id., at paragraph 95.

${ }^{64}$ Nachova v Bulgaria, ECHR (Grand Chamber)(2005), Applications 43577/98 and 43579/98. See also K. Henrard, 'Noot bij Nachova t. Bulgarije, EHRM (Grote Kamer) 6 juli 2005', EHRC 2005/97, 969-975.

${ }_{65}$ Milanovic v Serbia, ECHR (2010) Application 44614/07.

${ }^{66}$ See for a further discussion K. Henrard, 'Noot bij Milanovic t. Servië en Mizigarova t. Slovakije, 14 december 2010, EHRC 2011/39, 417-422.

67 Jakobski v Poland, ECHR (2010) Application 18429/06. See also Waddington (2011), above n. 60, at 197.

68 For an extensive discussion see Ast, above n. 61, especially at 89-91.

69 See inter alia S. Joseph, J. Schultz and M. Castan, The International Covenant on Civil and Political Rights: Cases, Materials and Commentary (2004), at 694; Ch. Tobler, Indirect Discrimination: A Case Study into the Development of the Legal Concept of Indirect Discrimination under EC law (2005), at 57.

70 In the words of Ast: 'systemic discrimination is a discriminatory process which amounts to a system:
} 
discrimination is meant to counter these systemic forms of discrimination, ${ }^{71}$ while being focused on substantive or genuine equality.

Reasonable accommodation measures can be perceived as an essential means of countering, or even preventing, such disproportionate impact, by taking into account the specific circumstances of the person(s) concerned. ${ }^{72}$ Nevertheless, it is important to explicitly identify duties of reasonable accommodation in addition to the prohibition of indirect discrimination. The reason why this is the case is nicely captured by Lisa Waddington, who points out that the "prohibition of indirect discrimination does not clearly enunciate a duty to accommodate, and this may only be recognized or understood by (specialized equality) lawyers and judges. Employers and other parties may be unaware that the prohibition to indirectly discriminate can include within it a positive duty to accommodate' ${ }^{73}$ Although Ast qualifies the right to reasonable accommodation as the corollary of indirect discrimination, he does acknowledge that there are various ways to address the disproportionate impact inherent in indirect discrimination, not all of which amount to reasonable accommodation. ${ }^{74}$ In other words, merely relying on the prohibition of indirect discrimination may not be adequate to provide accommodation in all appropriate cases. ${ }^{75}$

The preceding paragraphs have demonstrated how duties of reasonable accommodation concern a generally applicable dimension of the equality principle, which is not in principle limited to a particular ground of differentiation, and could thus also be used in relation to the ground of religion. Identifying such duties of reasonable accommodation in the religious field would actually form a logical development of the jurisprudence of the ECtHR.

As religious diversity is steadily increasing in states, public authorities feel the need to manage this diversity. The population adhering to the traditional religions in the region is not always receptive to measures that allow for the expression of separate new religious identities, and controversies soar when these measures are perceived to grant privileges to persons belonging to (de facto) religious minorities. ${ }^{76}$ Several concerns intersect in these controversies, including concerns of illegitimate discrimination, threats to duties of state neutrality and concerns of hampered integration, potentially jeopardising social cohesion and social harmony.

The following paragraphs will focus on the legal arguments and will discuss potential tensions between reasonable accommodation measures on the ground of religion on

it derives from a concatenation of actions, often unintentional, which involve several individuals but also operational rules and practical facilities' (Ast, above n. 61, at 92).

${ }_{71}$ Id.

72 This is (again) an important line of reasoning relied upon in, for example, Canada; see Bouchard and Taylor, above n. 11, at 24-25, where they argue that duties of reasonable accommodation are meant to counter or even prevent instances of (prohibited) indirect discrimination. This argumentation line is also followed by the Advisory Committee on Integration and Reasonable Accommodation in the Schools, above n. 23, at 35. See also Bribiosa, Ringelheim and Rorive, above n. 18, at 160.

The EU Network of Independent Experts on Fundamental Rights also adopts this line of reasoning in its Thematic Comment no 3, dedicated to 'Protection of Minorities in the EU' (2005), at 34, where it refers to a duty on public and private parties to "provide reasonable accommodation to all religious faiths, where the application of generally applicable and neutral [policies] might otherwise result in indirect discrimination on the grounds of religious belief'. The European Commission 2005 Framework Strategy on Non-Discrimination and Equal Opportunities for All arguably hints at the use of duties of reasonable accommodation that are not confined to the ground of disability by arguing that 'the EU should reinforce its efforts to promote equal opportunities for all, in order to tackle the structural barriers faced by migrants, ethnic minorities, the disabled, older and younger workers and other vulnerable groups' (at 2 and 10; see also FRA, Respect for and Protection of Persons Belonging to Minorities 2008-2010 (2011), at 27).

73 Waddington (2011), above n. 60, at 194.

74 Ast acknowledges, for example, that a disproportionate impact of a measure without reasonable and objective justification can also be remedied by simply abolishing that measure: Ast, above n. 61, at 96. See also below in the conclusion.

75 Waddington (2011), above n. 60, at 194.

76 See inter alia Jézéquel, above n. 7, at 22; Jackson Preece, above n. 27 at 118-126 (and also reflected in the title). See also T. Ramadan, 'Bringing About Harmonious Coexistence in Pluralist Societies', in Council of Europe (ed.), Institutional Accommodation and the Citizen: Legal and Political Interaction in a Pluralist Society (2010), at 167. 
the one hand, and the prohibition of discrimination and duties of state neutrality on the other. Throughout the analysis, the importance is emphasised of proper awarenessraising campaigns aimed not only at administrators, ${ }^{77}$ but also at the population at large, ${ }^{78}$ in order to enlighten them about the intrinsic relationship between accommodation measures and substantive equality, while demonstrating that these measures are in line with the fundamental tenets of the human rights paradigm, particularly the prohibition of discrimination and the freedom of religion.

\section{Are Duties of Reasonable Accommodation on the Basis of Religion in Line with the Prohibition of Discrimination?}

It has already been mentioned and confirmed by the examples given above that measures of reasonable accommodation tend to imply differential treatment ${ }^{79}$ between those who benefit from the measures and those who do not. In the context of religious diversity, the differentiations concerned can mostly be qualified as (direct or indirect) differentiations on the basis of religion. In this respect, non-religious persons could claim that identifying duties of reasonable accommodation on religious grounds would by definition not benefit them, and thus have a disproportionate impact upon them. This would imply a claim of indirect discrimination on the ground of religion. However, in so far as complaints would be voiced by persons who want an extra day off, for example, to spend with their friends or to go sailing, this can easily be met by pointing to the substantial differences between fundamental rights interests on the one hand, and other interests on the other. When persons also want an extra day off in order to spend more time with their children, they may invoke their right to family life, but the right to family life does not enshrine the right to spend as much time as possible or as much time as one like with one's family.

Certainly, it is generally accepted that not all differentiations amount to prohibited discrimination. The overall formula used is that when a differentiation has a reasonable and objective justification, this differentiation would not amount to a prohibited discrimination. This reasonable and objective justification would, in turn, require a legitimate aim for the differentiation, as well as a relationship of proportionality between the differentiation and the legitimate aim. ${ }^{80}$ There is no exhaustive enumeration of legitimate aims that can be invoked, but the overarching goal of substantive equality is surely included ${ }^{81}$ In any event, the emphasis is on the need for the differentiation to be proportionate to the particular legitimate aim.

One could argue that this proportionality check is already taken care of in relation to duties of reasonable accommodation, as is expressed in the qualification reasonable. ${ }^{82}$ Indeed, only accommodations that are reasonable in the circumstances of the concrete case need to be made. The standard usually used to determine this reasonability is that it should not impose an undue or disproportionate burden or hardship on the duty bearer, implying that it should not result in excessive difficulties ${ }^{83}$ It has already been clarified that relevant factors in measuring hardship predominantly pertain to financial costs or threats to the proper functioning of the institution for the employer, service provider etc. Nevertheless, these factors also encompass fundamental rights of others, referring to those that do not benefit from the accommodation. In other words, possible discrimination against third parties can play a role in the determination of whether the hardship caused by accommodation duties is undue or not. Thus, it can be argued

\footnotetext{
77 Inter alia Bouchard and Taylor, above n. 11, at 66.

78 Inter alia Bosset and Foblets, above n. 7, at 53.

9 Installing a ramp and an elevator would not do this, as it would benefit all employees, guests, etc., not only the ones with a handicap.

${ }^{80}$ Inter alia K. Henrard, Equal Rights versus Special Rights? Minority Protection and the Prohibition of Discrimination (2007), at 40.

${ }_{81}$ In contrast with the limitation clauses attached to several human rights such as the freedom to manifest one's religion, the right to respect for privacy, etc.

82 See also Waddington (2011), above n. 60, at 189.

83 Waddington (2007), above n. 1, at 635-636.
} 
that when an accommodation is not considered to cause undue hardship, this would imply that the measures concerned do not entail prohibited discrimination (against third parties).

Nevertheless, in view of the controversial nature of reasonable accommodation (and the related need for awareness raising), it seems warranted to make explicit how reasonable accommodation on the basis of religion and related differential treatment can avoid falling foul of the prohibition of discrimination on the basis of religion. This is particularly interesting because it can be argued that religion concerns a suspect ground of differentiation. In principle, suspect grounds would trigger heightened scrutiny, ${ }^{84}$ which implies that differentiations on these grounds are more or less presumptively invalid. ${ }^{85}$ Indeed, the higher the level of scrutiny, the more demanding requirements need to be met for the measure to be legal. When the level of scrutiny is very high indeed, it will be virtually impossible to justify a differentiation on this ground. Ultimately this can de facto entail a presumption of illegality for a differentiation on the ground concerned.

However, it can be questioned whether religion is indeed a suspect class, especially considering the supervisory practice of the ECtHR. In theory, there appear to be many indications that religion could indeed qualify as a suspect ground. In terms of more fundamental arguments to identify suspect grounds, three criteria have been put forward, that arguably all apply to the ground of religion. It has been argued that (1) suspect classes concern immutable characteristics or characteristics that are inherent to one's ego, and (2) concern features that are irrelevant for one's functioning in society (in the sense that it should not matter to decide whether or not one gets a job, a promotion, or access to public services). (3) Classes will also be suspect when they refer to a group which has historically suffered from unjustifiable discrimination and therefore is especially vulnerable to such treatment. While gender and race may first come to mind, in Europe one should not forget the religious wars in the Middle Ages and the persecution of Jews during the Holocaust. In terms of formal criteria, it has been argued that suspectedness would be reflected by the explicit enumeration of a ground in the non-discriminationclauses (which is definitely the case for religion). However, it needs to be acknowledged that, in contrast with other suspect grounds like gender and race, there is still no legally binding convention dedicated to the prohibition of discrimination on the basis of religion. ${ }^{86}$

The supervisory practice of the Court is moreover rather ambivalent about the suspect nature of religion. The Court most often identifies a ground as suspect when it explicitly requires 'very weighty reasons' to justify a differentiation on that ground. ${ }^{87}$ Grounds that are generally accepted as being suspect, also in the jurisprudence of the ECtHR, include race and gender. ${ }^{88}$ The ECtHR arguably recognised this suspect status

84 Inter alia A.W. Heringa, 'Standards for Review for Discrimination: the Scope of Review by the Courts', in T. Loenen and P.R. Rodriguez (eds.), Non Discrimination Law: Comparative Perspectives (1999), at 2627 and 29-30.

85 K. Henrard, 'Boosting Positive Action: the Asymmetrical Approach towards Non-discrimination and Special Minority Rights', 71 Heidelberg Journal of International Law 2, at 393 (2011).

${ }_{86}$ It is also striking that it took over twenty years to achieve consensus on the Declaration on the Elimination of All Forms of Intolerance and of Discrimination based on Religion or Belief, while the Declaration on the Elimination of All Forms of Racial Discrimination was virtually immediately adopted and quickly followed by a legally binding convention (already in 1965). Notwithstanding several calls to develop a convention on religious discrimination, this has never materialised, and will not do so for the foreseeable future: see inter alia C. Evans, 'Religious Freedom in European Human Rights Law: the search for a guiding conception', in M.W. Janis and C. Evans (eds.), Religion and International Law (1999), at 387; J. Temperman, '25th Anniversary Commemoration of the Adoption of the 1981 UN Declaration on the Elimination of Intolerance and Discrimination based on Religion or Belief: a report', 2 Religion and Human Rights (1-2), 19-30 (2007).

87 Inter alia Henrard (2011), above n. 85, at 385.

88 It should be noted that the UN knows conventions that are dedicated to combating discrimination on one particular ground. Arguably this indicates that the grounds concerned are considered suspect: the Convention on the Elimination of Discrimination against Women and the Convention on the Elimination of All Forms of Racial Discrimination are clear cases on this point.

It is striking that the ECJ and the Human Rights Committee, reviewing compliance with the ICCPR, do not clearly and explicitly adopt various levels of scrutiny. The baseline level of scrutiny of the ECJ tends to be rather high, even for a ground such as age (as was visible in various judgments since the Case 
of religion in a 1993 case concerning Jehovah witnesses, by indicating that 'a distinction based essentially on a difference in religion is not acceptable'. ${ }^{89}$ Nevertheless, in subsequent cases the Court tended to carefully avoid this qualification and did not hint at this qualification of suspect class, even in cases with similar factual backgrounds, such as Palau Martinez v France..$^{90}$ It was argued elsewhere that the Court's unease concerning religious discrimination and the determination of a heightened level of scrutiny appears related to its assessment of cases that centre around particular churchstate relations in a country. ${ }^{91}$ Choices regarding church-state relations obviously tend to imply a differentiation on the basis of religion. This is most visible in systems of a state church or national church, as well as in systems of recognised religions (cooperation schemes). If religion were explicitly recognised as a suspect class, the ensuing heightened level of scrutiny would be very difficult if not impossible to reconcile with the steady line of jurisprudence following which the Court grants states a wide margin of appreciation concerning state-church relations (in view of the absence of a common European standard in the matter). ${ }^{92}$

However, in line with the evolutive interpretation by the Court, a series of judgments in December 2010 appeared to indicate that the Court does acknowledge that religion is a suspect class of differentiation. The Court has indeed explicitly stated in Savez Crkava and others $v$ Croatia ${ }^{93}$ that criteria that need to be fulfilled by religious groups in order to obtain a special status entitling it to various rights and privileges merit particular scrutiny. ${ }^{94}$ Similarly, it has emphasised in Religionsgemeinschaft der Zeugen Jehovas $v$ Austria ${ }^{95}$ and Kimlya and others $v$ Russia ${ }^{96}$ that criteria used in systems of recognition should be non-discriminatory and the related procedures should be transparent, thus meaning that all religions should have a fair chance of getting this status. The reasoning adopted in these cases reveals that the Court no longer shies away from using a higher level of scrutiny which de facto reduces the broad margin of appreciation of states in religious matters ${ }^{97}$ (including when it pertains to the area of church-state relations). Unfortunately, however, the Grand Chamber decision in Lautsi v Italy ${ }^{98}$ breaks this trend. ${ }^{99}$ Even if there were a clear trend indicating the consideration of religion as a suspect ground (and thus a de facto presumption of illegality for differentiations on the basis of religion), this could still be reconciled with actual duties of reasonable accommodation on the basis of religion, namely through distinguishing the symmetrical and asymmetrical approach to the scrutiny of suspect grounds of differentiation.

144/04 Mangold v Helm [2005] ECR I-9981 judgment), whereas there are many more legitimate reasons to distinguish on the basis of age than, for example, on the basis of gender or race.

${ }^{89}$ Hoffmann v Austria, ECHR (1993), Application 12875/87, at paragraph 36.

$90 \quad$ Palau Martinez v France, ECHR (2003), Application 64927/01.

91 K. Henrard, The Ambiguous Relationship between Religious Minorities and Fundamental (Minority) Rights (2011), at 71-72.

${ }_{92}$ It is even established jurisprudence that a state church is not, as such, contrary to the Convention: see inter alia Henrard (2011), above n. 91, at 71. See also M.C. Nussbaum, Liberty of Conscience: In Defense of America's Tradition of Religious Equality (2008), at 9, 11 and 21.

93 Savez Crkava and others v Croatia, ECHR (2010), Application 7798/08.

94 The Court builds here on earlier case law in which it had become more outspoken and demanding about systems of 'recognition' used by states in relation to religions and religious communities.

${ }_{95}$ Religionsgemeinschaft der Zeugen Jehovas v Austria, ECHR (2008), Application 40825/98.

96 Kimlya and others $v$ Russia, ECHR (2009), Applications 76836/01 and 32782/03.

97 See also the analysis above on Milanovic $v$ Serbia, above $n$. 65. This higher level of scrutiny or higher demands imposed on states is furthermore transposed to the analysis under Article 9 ECHR in itself, as was arguably visible in Jakobski $v$ Poland, above n. 67.

98 Lautsi v Italy, ECHR (2011) Application 30814/06.

99 See also K. Henrard, 'Shifting Visions of Indoctrination and the Margin of Appreciation Left to States', 6 Religion and Human Rights 3, at 245-251(2011). 


\subsection{The Asymmetrical Approach to the Scrutiny of Suspect Grounds of Differentiation}

The ultimate conclusion regarding whether or not the prohibition of discrimination is respected depends to a great extent on the level of scrutiny adopted in relation to the proportionality principle. The level of scrutiny adopted by a supervisor is not as such prescribed by the legislative norms, and is thus ultimately a question of judicial practice and judicial choice, situated at the level of interpretation and application of the standards. ${ }^{100}$

The current supervisory practice of the ECtHR in particular displays more than one level of scrutiny, which for suspect grounds tends to be high and the demands towards the justifications put forward by the state are similarly high. However, when a supervisory body identifies suspect grounds, this raises the question of whether a particular ground of differentiation is suspect per se, and thus per se triggers heightened scrutiny, or whether other considerations also play a role, thus meaning that a ground may be suspect and trigger heightened scrutiny in some instances and not in others.

Here, the distinction between a symmetrical and an asymmetrical approach to the scrutiny of suspect grounds of differentiation comes into play, which is again a matter of judicial choice about which supervisory bodies differ. ${ }^{101}$ The symmetrical approach takes the per se position, through which any use of a suspect ground leads to heightened scrutiny, irrespective of the context and goal of the measure concerned. The asymmetrical approach does not follow this per se route, and factors in other considerations. For example, while gender is generally considered to be a suspect ground of differentiation, the asymmetrical approach would question whether heightened scrutiny should be used for differentiations disadvantaging men (and not women). In other words, the asymmetrical approach would consider it relevant which group is disadvantaged by a particular measure. In so far as a particular measure disadvantages an already disadvantaged group, this would trigger heightened scrutiny. Conversely, if the measure concerned would disadvantage a privileged group, this would not necessarily trigger heightened scrutiny.

In this article, asymmetrical and symmetrical terms are used to refer to the closely related question of whether the primary goal of a differentiation on a particular ground matters for the purposes of determining the appropriate level of scrutiny. ${ }^{102}$ This is indeed the question with regard to accommodation measures.

Clearly, these measures concern differential treatment which is meant to be beneficial for persons belonging to a particular group. In other words: the primary goal of accommodation measures is not invidious discrimination, but the addressing of the disadvantages of (the barriers encountered by) persons belonging to particular groups. Nevertheless, when a measure advantages some people (belonging to particular groups), this implies that others do not receive that advantage, and could thus be considered to suffer a disadvantage, depending on the exact context and the position of the others. Still, accommodation measures are qualitatively different compared to forms of invidious discrimination. The primary goal of the former measures is beneficial (towards the disadvantaged group), while the disadvantage for the group which does not experience these barriers is rather a form of collateral damage.

The question in terms of the symmetrical versus the asymmetrical approach is then whether the beneficial nature of the primary goal of reasonable accommodation measures should entail a reduction in the level of scrutiny, or at least not trigger the use of heightened scrutiny. The symmetrical approach implies that no matter what the goal or underlying reason for the differential treatment of a suspect class is, such a

\footnotetext{
100 It is, for example, striking, that the ECtHR took until the 21th Century to explicitly recognise that race was a suspect ground, triggering heightened scrutiny, while this was already recognised by other international supervisory bodies and national courts several decades earlier. Furthermore, the fact that some supervisors distinguish two and others more levels of scrutiny (for example, the US Supreme Court), also supports this view.

${ }_{101}$ For a more elaborate reasoning along these lines, see Henrard (2011), above n. 85, at 389-392.

102 See also Henrard (2011), above n. 85, at 390.
} 
differentiation will always be scrutinised strictly. This more or less implies a presumption of illegality. However, following the asymmetrical approach, one would not resort to heightened scrutiny when the differentiation concerned is aimed at furthering substantive equality. This does not amount to a presumption of legality, but rather the absence of a presumption of illegality. It can be argued that such an asymmetrical approach takes into account differences in contextual circumstances and is thus in line with the more general visible shift towards substantive or real equality noted earlier.

Clearly the asymmetrical approach would favour the legitimacy of reasonable accommodation measures, the basic rationale of which is also substantive or genuine equality. In other words, in so far as supervisors choose to adopt an asymmetrical approach to levels of scrutiny for the prohibition of discrimination, there would be no (actual) tension between duties of reasonable accommodation on the one hand, and the prohibition of discrimination on the other. ${ }^{103}$

\section{Are Duties of Reasonable Accommodation on Religious Matters in Line with the Freedom of Religion?}

When investigating whether duties of reasonable accommodation in religious matters are compatible with the human rights paradigm, various interpretation lines of the ECtHR under the freedom of religion are also relevant. Interestingly, and actually rather similarly to evaluation under the prohibition of discrimination, some interpretation lines regarding the freedom of religion embrace such duties of reasonable accommodation, while others reveal potential tensions. Also, it will be demonstrated here that the reality of the tension depends on the interpretative choices made by the supervisor, particularly about the meaning and implications of state neutrality.

\subsection{State Duties: not only Negative but also Positive, related to Real and Effective Enjoyment of Rights}

First of all, it needs to be emphasised that the ECtHR has a rather extensive jurisprudence identifying positive state obligations, above and beyond the negative state obligations of non-interference. This jurisprudence has developed in order to strengthen the effective protection of human rights, and thus strengthens the internal rational of the human rights paradigm. ${ }^{104}$ Whereas this rational is equally valid for all human rights (enshrined in the ECHR), it needs to be acknowledged that there are also remarkable differences between rights, in the sense that the Court has not, in relation to all rights, recognised an equally expansive range of positive state obligations. Article 8 is an example of an article which is blessed with an extensive range of positive state obligations. For Article 9, on the other hand, these positive obligations tend to be confined to the sphere of protection against acts of intolerance by public authorities and private parties. ${ }^{105}$ In other words, they do not go as far as obliging states to actively, positively accommodate the needs of religious groups (often religious minorities).

Yet, it is fairly easy to argue that duties of positive accommodation are equally important in realising an effective enjoyment of the freedom to manifest one's religion

\footnotetext{
103 However, it should be noted, though, while there may not be full agreement on the exact relationship between duties of reasonable accommodation on the one hand, and the prohibition of discrimination on the other, there is a rising recognition that NOT respecting these duties of reasonable accommodation would amount to a prohibited discrimination. Similarly, Thlimmenos has clarified that not treating different persons differently would amount to a prohibited instance of discrimination. Something that is mandated by the prohibition of discrimination cannot, at the same time, fall foul of that prohibition.

104 Inter alia K. Boyle, 'Freedom of Religion in International Law', in J. Rehman \& S.C. Bréau (eds.), Human Rights and International Law: A Critical Examination of Islamic State Practice (2007), at 29; Y. Arai, 'The System of Restrictions', in P. van Dijk et al (eds.), Theory and Practice of the European Convention on Human Rights (2006), at 349; D. Xenos, The Positive Obligations of the State under the European Convention on Human Rights (2012), at 91.

105 See also Henrard (2011), above n. 9, at 55-56.
} 
as well as religious pluralism, which is considered to belong to the core rational of Article 9. ${ }^{106}$ It has even been argued that accommodation of religious practices of different faith communities should follow, unless there are strong policy considerations not to do so. ${ }^{107}$ This can actually be related to the fact that in Canada, for example, the courts have deduced duties of reasonable accommodation in religious matters not only from the right to equal treatment, but also from the freedom of religion. ${ }^{108}$

Nevertheless, one of the guiding principles under Article 9 and the freedom of religion is that states are obliged to be neutral and impartial towards the various religions in their territory. ${ }^{109}$ Obviously, one could perceive a tension between duties of reasonable accommodation on the ground of, on the one hand, religion, and on the other, duties of state neutrality. Yet, it is important to emphasise that the reality of this tension depends on the interpretation of state neutrality.

\subsection{Duties of State Neutrality: State Neutrality?}

State neutrality is closely related to the separation between church and state. Nevertheless, these concepts concern different things: while separation between church and state is mostly concerned with the institutional ties between state and religion, neutrality is rather a substantive ideal, concerning the organisation and content of government policy.

Be that as it may, there is a range of different visions of what neutrality requires, ${ }^{110}$ two opposites being exclusive versus inclusive neutrality. Following exclusive neutrality, the government is supposed to detach itself from religion, and religion should not play any role in policy choices. ${ }^{11}$ This vision of neutrality tends to be related to the French laicité, which implies that the manifestation of religion is a private matter, and is not supposed to be practiced in the public arena. It can be argued though that this radical exclusion of religion from the public space implies a denial of the core of the freedom of religion. Certainly, religion is a fundamental part of many people's identity. Requiring them to leave that behind when they enter the public space would be asking them to abandon an essential part of themselves. ${ }^{112}$

\footnotetext{
106 Inter alia D. Augenstein, Religious Pluralism and National Diversities: Dilemmas of European Human Rights Jurisprudence, <http://www.irmgard-coninx-stiftung.de/fileadmin/user_upload/pdf/Cultural Pluralism/Religion/Essay.Augenstein.pdf $>$ (year?), at 2 ; T. Parker, 'The Freedom to Manifest Religious Belief: An Analysis of the Necessity Clauses of the ICCPR and the ECHR', Bepress Legal Series: paper 1107 (2006) at 7; F. Tulkens, 'The European Convention on Human Rights and Church-State Relations: Pluralism vs Pluralism', 30 Cardozo Law Review 6, at 2579 (2006); B. Vermeulen, 'Freedom of Thought, Conscience and Religion', in P. van Dijk et al (eds.), Theory and Practice of the European Convention on Human Rights (2006), at 764. A lead judgment here is Kokkinakis v Greece, ECHR (1993), Application $14307 / 88$, at paragraph 31 .

107 Inter alia P. Cumper, 'The Accommodation of Uncontroversial Religious Practices', in L.M.P. Loenen and J.E. Goldschmidt (eds.), Religious Pluralism and Human Rights in Europe: Where to Draw the Line? (2007), at 205-209. According to Bader, liberal democracy requires flexible (not absolute) accommodation of religious practices, see inter alia V. Bader, Secularism or Democracy: Associational Governance of Religious Diversity (2007), at 136, 138, 140, and especially 164.

108 Bribiosa, Ringelheim and Rorive, above n. 18, at 146-157. See also Woehrling, above n. 30, at 370.

This close interrelationship of the right to equal treatment and the right to manifest one's religion with regard to duties of reasonable accommodation is also supported by American academics, see inter alia Rozenzweig, above n. 30, at 2528 .

${ }_{109}$ Inter alia W. van der Burg, Het ideaal van de neutrale staat: Inclusieve, exclusieve en compenserende visies op godsdienst en cultuur (2009), at 19.

110 See inter alia the discussion by Woehrling of the understandings of neutrality in the US, France and Canada: Woehrling, above n. 30, at 371-368.

111 Van der Burg, above n. 110, at 41.

112 Note also the concerns voiced about the so-called concern with state neutrality since $9 / 11$ in the sense that it was not really about state neutrality but rather about 'a means of controlling some forms of public religious expression and not others': G. Mahrouse, 'Reasonable accommodation in Québec: the Limits of Participation and Dialogue', 52 Race \& Class 1, at 92-93 (2010). See also E. Santoro, 'Ha da passa a nuttata: Reasonable Accommodation, a Tool for Defending Coexistence Based on Respect for Rights in a Pluralist Society', in Council of Europe (ed.) Institutional Accommodation and the Citizen: Legal and Political Interaction in a Pluralist Society (2010), at 210-211.
} 
Inclusive neutrality ${ }^{113}$ positive neutrality,${ }^{114}$ or neutrality as evenhandedness, ${ }^{115}$ does not exclude religion from the public space and state policies. Rather, it interprets duties of state neutrality pertaining to religious matters as implying that the government should not advantage one religion over another in its policies. ${ }^{116}$ This could also be realised by making space for the manifestations of all religions in the public sphere, ${ }^{117}$ respecting the ideal of substantive equality which would tie back to the proportionality principle. In other words, inclusive neutrality implies that the government is obliged to support each citizen proportionally in the enjoyment of one's religious identity. ${ }^{118}$

It can thus be argued that inclusive neutrality would further substantive equality, while respecting the core of the freedom to manifest one's religion and realising the effective enjoyment of the freedom of religion. Consequently, when one wants to maintain and promote the internal coherence of the human rights paradigm, inclusive neutrality would be the preferred interpretative option.

Clearly, inclusive neutrality is open towards measures of reasonable accommodation, which are similarly inclusive in nature, while their basic rationale is also based upon substantive or genuine equality. ${ }^{119}$ In other words, in so far as supervisors choose the interpretation of duties of state neutrality as referring to inclusive neutrality, there would be no (actual) tension between duties of reasonable accommodation on the one hand, and duties of state neutrality under the freedom of religion on the other (thus confirming the holistic nature of the fundamental rights paradigm).

\section{Conclusion}

The preceding reasoning has demonstrated that the reading of the principle of equal treatment and the prohibition of discrimination which, on the one hand, supports duties of reasonable accommodation also on the ground of religion, and, on the other, the identification of accommodation duties under the freedom of religion (notwithstanding duties of state neutrality), are mutually supportive, as they further both substantive equality and the effective protection of the freedom of religion. Certainly, these readings imply that one adopts an asymmetrical approach to the scrutiny of suspect grounds of differentiation (in terms of the prohibition of discrimination), and an understanding of inclusive (state) neutrality under the freedom of religion. Arguably, these interpretations should be preferred, as they confirm and strengthen the overall coherence of the human rights paradigm and its holistic nature. Indeed the holistic nature of human rights implies that it should be possible to interpret different rights without internal contradiction, thus displaying internal coherence.

In view of the controversies that tend to surround duties of reasonable accommodation on the ground of religion, it is important to raise awareness among the public at large

113 Van der Burg, above n. 109, at 40.

114 S.V. Monsma, Positive Neutrality: Letting Religoius Freedom Ring (1992). Sometimes Veit Bader also uses the concept 'benign state neutrality' (V. Bader, 'Dilemmas of Ethnic Affirmative Action. Benign State-neutrality or Relational Ethnic Neutrality?', 2 Citizenship Studies 3 (1998)), or 'relational neutrality' (V. Bader, 'Religions and States: a new typology and a plea for non-constitutional pluralism', 6 Ethical Theory and Moral Practice 1, at 5-91 (2003)), in order to refer to the same thing.

115 Bader (2003), above n. 114, at 5; J. Carens, Culture, Citizenship and Community: A Contextual Exploration of Justice as Evenhandedness (2000). See also the 'open secularism' model allegedly advocated by Bouchard and Taylor in their 2008 Final Report: M. Sharify-Funk, 'Muslims and the Politics of "Reasonable Accommodation": Analyzing the Bouchard-Taylor Report and its Impact on the Canadian Province of Québec', 30 Journal of Muslim Minority Affairs 4, at 542-543 (2010).

116 Van der Burg, above n. 109, at 16.

117 See also Woehrling, above n. 30, at 375-378, where he discusses the prevailing interpretation of neutrality in Canada as evenhandedness. He emphasises that state support of religion is problematic in so far as this support is discriminatory or creates social pressure on non-adherents. These problematic features would not be present in instances of reasonable accommodation on the basis of religion, since this would not impose pressure on non-adherents to behave in ways contrary to their religious beliefs. He calls this a tolerant and open interpretation of the principle of religious neutrality.

118 See also Van der Burg, above n. 109, at 41.

119 See also J. Maclure, Reasonable Accommodation and Recognition as an Integration Policy Tool, Policy Brief, $<$ www.fondapol.org $>$ (2006). 
about the congruence between duties of reasonable accommodation on the ground of religion on the one hand, and the prohibition of discrimination and the freedom of religion on the other. ${ }^{120}$ In addition to awareness raising ${ }^{121}$ on the foundations/justifications of reasonable accommodation measures, it is also important to emphasise the limits of these accommodation duties, both in terms of interests of those that need to provide accommodation, and the fundamental rights (of non-discrimination) of those that do not benefit from the accommodation. ${ }^{122}$

Furthermore, awareness raising also has an important role to play in safeguarding the (potential) positive impact of accommodation in terms of integration and social cohesion. Reasonable accommodation of religious minorities has the clear potential to improve the participation of religious minorities, making them feel that they belong, and that they and their concerns are taken seriously, which would arguably improve their integration. Controversies about these measures and the related backlash clearly threaten social cohesion and harmony. ${ }^{123}$ Overall, it seems justified to conclude that the ECtHR would strengthen the overall coherence and consistency of its jurisprudence pertaining to the prohibition of discrimination and the freedom of religion, confirming the holistic nature of the human rights paradigm, if it would indeed explicitly identify duties of reasonable accommodation on the basis of religion.

Over time, this explicit use of the duties of reasonable accommodation could also lead to an increased awareness among public authorities, which would have an impact on the way they construct their general standards. ${ }^{124}$ This would actually reflect a development in Canada where the courts increasingly require pro-active adaptations of the general standards by the public authorities. Obviously, by making the general standards more inclusive, the additional need for individual instances of reasonable accommodation will markedly reduce, and thus also the related controversies. ${ }^{125}$

\footnotetext{
120 See also J.G. Reitz, R. Banerjee, M. Phan and J. Thompson, Religion, Religiosity and the Social Integration of Immigrant Ethnic Groups in Canada, <http://www.utoronto.ca/ethnicstudies/ReligionReligiosity.pdf $>$ (2008), at 22.

121 It should be highlighted that the importance of awareness raising is often emphasised in relation to minorities, their concerns, needs, and rights. It features prominently in the supervisory practice of the Advisory Committee under the Framework Convention for the Protection of National Minorities, see inter alia AC, Second Opinion on Romania, 24 November 2005, ACFC/OP/II(2005)007, at paragraphs 9 and 48 (regarding the relation between non discrimination and special measures for persons belonging to minorities), at paragraph 206 (on the need to increase awareness raising amongst public, politicians and media regarding the importance of tolerance and respect for diversity); AC, Third Opinion on Armenia, 20 April 2011, ACFC/OP/III(2010)006, at paragraph 75 (regarding the need to intensify awareness-raising measures on tolerance and anti-discrimination issues aimed at law-enforcement officials, the media, the judiciary and the public). See also J. Popjanevski, Minorities and the State in the South Caucasus: Assessing the Protection of National Minorities in Georgia and Azerbaijan (2006), at 11, 13, 56,58 and 75.

122 See also Jézéquel, above n. 7, at 318-322.

123 This was clearly the case in Canada/Québec in 2006-2007. The vehement discussions in the Netherlands about the religiously inspired wish not to shake hands with persons of the opposite sex also highlights this point.

${ }^{124}$ This rebalancing of the general standards through which all can benefit is also advocated by Tariq Ramadan as an important strategy in order to bring about harmonious coexistence in pluralist societies, see Ramadan, above n. 76, at 167.

${ }_{125}$ See also M. van den Brink, 'Equality as an Additional Standard for Decisions on the Accommodation of Religious Practices', in M.L.P. Loenen and J.E. Goldschmidt (eds.), Religious Pluralism and Human Rights in Europe: Where to Draw the Line? (2007), at 214-215, where the preference for inclusive solutions is emphasised.
} 